\title{
Aplikasi Pemilihan Supplier Menggunakan Metode Profile Matching (Studi Kasus: Toko Maju Jaya)
}

\author{
Elsa Oktariza, Iklima Ermis Is mail \\ Program Studi Teknik Informatika \\ Jurusan Teknik Informatika dan Ko mputer \\ Politeknik Negeri Jakarta \\ oktariza43@gmail.com, iklimaermis.ismail@tik.pnj.ac.id
}

Diterima: 10 Mei 2019. Disetujui 11 Mei 2019. Dipublikasikan 27 Mei 2019

\begin{abstract}
The supplier is a business run by parties who disburse a product to a person or a company. In carrying out its operational activities Maju Jaya Store get supply of products from various suppliers. There are several suppliers selling the same item with different offerings, making it difficult for the shop owner to decide on the supplier to be selected when going to the rest of the goods. Currently supplier selection is done by contacting one by one supplier via telephone to find the best offer. This certainly takes a lot of time as well as cost. Resolving the problems that have been exposed is with the construction of Decision Support System of supplier selection using Profile Matching Method. The supplier selection process begins with the determination of criteria and sub criteria, weighting criteria then calculating and grouping core and secondary factors, calculating the total value, and then the system will display the rank of the supplier to be selected for consideration in decision making. Based on the test that is done alpha and beta testing yield percentage of success equal to $100 \%$. While the real data comparison test and using Profile Matching Method has a success percentage $80 \%$.
\end{abstract}

Keywords: decision support system, profile matching, prototyping, supplier, yii2

\section{PENDAHULUAN}

Toko Maju Jaya merupakan suatu usaha yang bergerak di bidang peralatan rumah tangga yang berdiri sejak tahun 2012. Dalam melaksanakan kegiatan operasionalnya Toko Maju Jaya mendapatkan pasokan produk atau barang dari berbagai supplier. Pemilihan supplier adalah salah satu aspek penting yang menjamin kelancaran operasional perusahaan [1].

Berdasarkan hasil wawancara dengan pemilik toko, diperoleh informasi bahwa setiap supplier memiliki kelebihan dan kekurangan masing-masing. Sejak berdiri Toko Maju Jaya telah memiliki banyak supplier dengan menjual barang yang sama, sehingga sulit untuk memutuskan supplier yang akan dipilih saat melakukan restok barang. Terdapatnya beberapa kriteria dalam pemilihan supplier yang diharapkan seperti harga yang lebih rendah, kualitas atau mutu produk yang tinggi dan pelayanan yang memuaskan. Permasalahan yang terjadi yaitu pemilihan supplier dapat menghabiskan banyak waktu. Saat ini pemilihan supplier dilakukan dengan cara menghubungi satu persatu supplier via telepon. Apabila merasa tidak sesuai dengan supplier tersebut maka dilanjutkan dengan menghubungi supplier yang lain hingga menemukan penawaran terbaik. Saat menghubungi supplier terkadang terlewatkanya beberapa kriteria yang ditanyakan. Pemilihan supplier yang akan di hubungi pun masih mengandung unsur subjektivitas.

Pemilik toko telah memiliki beberapa kriteria dalam pemilihan supplier namun belum memiliki sebuah sistem. Penyelesaian permasalahan yang telah dipaparkan di atas yaitu dengan dirancang dan dibangunnya sistem pendukung keputusan dalam pemilihan supplier. Dengan adanya sistem dapat membantu pemilik toko dalam melakukan pemilihan supplier saat akan melakukan restok barang. Sistem ini akan menghasilkan perengkingan supplier berdasarkan kriteria yang telah ditetapkan. Hal ini pun dapat menghilangkan unsur subjektivitas dalam pemilihan.

\section{TINJAUAN PUS TAKA}

\section{A. Sistem Pendukung Keputusan}

Sistem Pendukung Keputusan merupakan suatu pemecahan masalah dimana dapat membantu si pengambil keputusan dalam menangani permasalahan yang dihadapi, baik dari sisi penyediaan informasi maupun dari kemampuan komunikasi dalam memecahkan permasalahan [2]. Sistem Pendukung Keputusan merupakan suatu sistem informasi dalam pengambilan keputusan dimana dapat membantu managemen dalam memecahkan suatu permasalahan. Permasalahn yang muncul biasanya bersifat semi terstruktur. Terdapat berbagai alternative yang muncul dari sistem ini 
yang dijadikan sebagai bahan pertimbangan [3]. Sistem Pendukung Keputusan bertujuan untuk menyediakan alternatif pilihan terbaik diantara beberrapa alternatif yang ada serta dapat mengarahkan para pengambil keputusan yang merasa sulit dalam memutukan suatu hal.

\section{B. Profile Matching}

Profil Matching merupakan suatu metode dimana terlebih daulu ditentukan nilai ko mpetensi(ke mampuan) yang diperlukan oleh suatu jabatan. Kemampuan tersebut harus dipenuhi oleh calon yang akan dinilai kinerjanya [4]. Metode Profile Matching merupakan suatu metode dalam Sistem Pendukung Keputusan dimana membandingkan data kriteria yang ditentuan dengan berbagai alternatif yang ada. Dalam metode ini dikenal dengan istilah GAP [3]. Pada metode Profile Matching selisih setiap nilai data terhadap nilai minimum masing-masing variabel, merupakan gap yang kemudian ditetukan bobotnya. sehingga dapat diketahui perbedaan ko mpetensinya (GAP).

Pada metode ini terdapatnya ketentuan dalam menentukan bobot. Langkah Metode Profile Matching menurut Kusrini adalah sebagai berikut [6]:

1. Kriteria Penilaian

Pada tahap ini ditentukan bobot nilai masing masing kriteria yang digunakan sebagai bobot preferensi untuk menentukan selisih dari kriteria ideal suatu alternatif dengan nilai yang dimiliki.

2. Pemetaan Gap Kompetensi

Pemetaan Gap merupakan perbedaan kriteria yang dimiliki seseorang dengan kriteria yang diinginkan pengguna sesuai dengan kriteria penilaian. Rumus untuk pemetaan Gap:

Gap=Value Atribut - Value Target Pers.(1)

Dalam penentuan peringkat untuk setiap alternatif, diberikan bobot nilai sesuai dengan tabel berikut:

TAB EL 1 Pemetaan Gap

\begin{tabular}{ccl}
\hline $\begin{array}{c}\text { Selisih } \\
\text { Gap }\end{array}$ & $\begin{array}{c}\text { Bobot } \\
\text { Nilai }\end{array}$ & \multicolumn{1}{c}{ Keterangan } \\
\hline 0 & 5 & $\begin{array}{l}\text { Tidak ada selisih (Kompetensi sesuai } \\
\text { yang dibutuhkan) }\end{array}$ \\
\hline 1 & 4,5 & $\begin{array}{l}\text { Kompetensi individu kelebihan 1 } \\
\text { tingkat/level }\end{array}$ \\
\hline-1 & 4 & $\begin{array}{l}\text { Kompetensi individu kelebihan 1 } \\
\text { tingkat/level }\end{array}$ \\
\hline 2 & 3,5 & $\begin{array}{l}\text { Kompetensi individu kelebihan 2 } \\
\text { tingkat/level }\end{array}$ \\
\hline 3 & 3 & $\begin{array}{l}\text { Kompetensi individu kelebihan 2 } \\
\text { tingkat/level }\end{array}$ \\
\hline-3 & 2,5 & $\begin{array}{l}\text { Kompetensi individu kelebihan 3 } \\
\text { tingkat/level }\end{array}$ \\
\hline
\end{tabular}

\begin{tabular}{ccc}
\hline $\begin{array}{c}\text { Selisih } \\
\text { Gap }\end{array}$ & $\begin{array}{c}\text { Bobot } \\
\text { Nilai }\end{array}$ & \multicolumn{1}{c}{ Keterangan } \\
\hline 4 & 1,5 & $\begin{array}{l}\text { Kompetensi individu kelebihan 4 } \\
\text { tingkat/level }\end{array}$ \\
\hline
\end{tabular}

3. Perhitungan dan Pengelompokan Core dan Secondary Factor

Setelah menentukan bobot nilai gap dari suatu kriteria, kemudian tiap kriteria dikelompokkan lagi menjadi dua kelompok yaitu core factor dan secondary factor.

\section{- Corefactor}

Core factor merupakan aspek (kompetensi) yang menonjol atau paling dibutuhkan oleh suatu alternatif yang diperkirakan dapat menghasilkan kinerja optimal. Rumus untuk menghitung core factor:

$$
N C F=\Sigma N C / \Sigma I C
$$

Pers. (2)

Keterangan:

$\mathrm{NCF}=$ Nilai rata-rata core factor

$\mathrm{NC}=$ Nilai core factor

IC = Item core factor

- Secondary factor

Secondary factor adalah item-item selain kriteria yang ada pada core factor. Untuk menghitung secondary factor digunakan rumus:

$$
N S F=\Sigma N S / \Sigma I S
$$

Pers.(3)

Keterangan:

NSF = Nilai rata-rata secondary factor

NS = Nilai secondary factor

IS $=$ Item secondary factor

4. Perhitungan Total

Dari perhitungan core factor dan secondary factor dari tiap-tiap kriteria, kemudian dihitung nilai total dari tiap-tiap kriteria yang diperkirakan berpengaruh pada kinerja tiap-tiap profile. Untuk menghitung nilai total dari masing-masing kriteria digunakan ru mus:

$$
N=X \% N C F+(X) \% N S F
$$

Keterangan:

$\mathrm{N}=$ Nilai total kriteria

$\mathrm{NCF}=$ Nilai rata-rata core factor

$\mathrm{NSF}=$ Nilai rata-rata secondary factor

$\mathrm{X} \%=$ Presentase bobot preferensi kriteria dari core dan secondary factor

5. Perhitungan Penentuan Ranking 
Hasil akhir dari proses profile Matching adalah ranking dari kandidat yang diajukan untuk mengisi suatu posisi tertentu. Penentuan mengacu ranking pada hasil perhitungan yang ditunjukan oleh rumus:

Rank $=\sum(X \%) x$ The total value of the assessment criteria Pers.(5)

Keterangan:

$\begin{array}{ll}\mathrm{NCF} & =\text { Nilai rata-rata } \text { core factor } \\ \mathrm{NSF} & =\text { Nilai rata-rata secondary } \\ \text { factor } \mathrm{X} \% & =\text { Presentase nilai bobot preferensi } \\ \text { dari tiap kriteria } & \end{array}$

\section{Prototyping}

Metode Prototyping ini biasanya digunakan apabila pemilik sistem tidak mengetahui secara detail / belu m menguasi sistem yang akan dike mbangankan makanya diperlukan suatu gambaran agar pemilik memahami sistem yang dikerjakan [5]. Prototyping adalah suatu metode pengembangan sistem yang memungkin developer membuat suatu model software yang digunakan kepada client apabila client tidak dapat memberikan informasi-innformasi maksimal yang dibutuhkan [7].

Tahapan Metode Prototyping adalah sebagai berikut [8]:

1. Analisa kebutuhan $u$ ser

Tim pengembang dan pengguna akhir atau client sistem melakukan diskusi mengenai kebutuhan sistem yang akan dirancang.

2. Membuat prototype

Tim pengembang membuat prototype dari sistem sesuai dengan hasil diskusi yang telah dilakukan

3. Menyesuaikan prototype dengan keinginan user Tim pengembang dan client bertemu kembali untuk melakukan pembahasan mengenai prototype yang telah dirancang. Tahapan ini dilakukan untuk menanyakan kepada client apakah prototype yang dirancang telah sesuai dengan kebutuhan sistem.

4. Membuat sistem baru

Tim pengembang membuat sistem berdasarkan prototype yang telah dirancang, dimana sebelumnya prototype tersebut sudah disepakati dengan client

5. Melakukan pengujian sistem

Client melakukan uji coba terhadap sistem yang telah dirancang

6. Menyesuaikan dengan kebutuhan user

Pada tahapan ini setelah dilakukannya pengujian sistem, jika hasilnya sesuai dengan kebutuhan, maka dilanjutkan ke tahapan menggunakan sistem.

7. Menggunakan sistem

\section{Supplier}

Supplier merupakan suatu mitra yang penting bagi perusahaan. Suatu perusahaan tidak hanya menuntut untuk bertindak sesuai prinsip atau standar tertentu, mereka juga mengharapkan rantai pasokan perusahaan dan tentunya ranti pasok ini berpegang pada kode etik. Dalam penerapannya perusahaan pun harus memastikan agar supplier yang dimiliki tetap memahami aturan-aturan dan prinsip yang berkelanjutan [9]. Supplier merupakan suatu pihak yang dijadikan sebagai sumber barang atau jasa. Supplier disebut juga seseorang yang menyedikan produk, komoditas atau jasa kepada konsumen, bias anya melalui distributor. [10].

Pemasok atau supplier merupakan seseorang atau suatu pihak yang menjalankan usaha menyalurkan atau memasarkan sesuatu barang atau produk ke seseorang atau perusahaan dalam jangka waktu tertentu. Pemilihan supplier harus dilakukan dengan baik karena akan berpengaruh terhadap bisnis atau usaha yang dijalani.

E. Yii2

Yii2 adalah kerangka kerja PHP berbasis komponen dengan performansi tinggi untuk pengembangan aplikasi web berskala besar. Ia menyediakan reusabilitas maksimum dalam pemrograman web dan bisa mengakselerasi proses pengembangan secara signifikan. Nama Yii (dieja sebagai /i:/) singkatan dari easy, efficient dan extensible (mudah, efisien, dan bis a diperluas) [11]. Yii Framework atau lebih dikenal dengan sebutan Yii adalah suatu kerangka kerja berbasis PHP dan bersifat open source. Yii Framework mengadopsi konsep MVC (Model - View - Controller) [12].

\section{PERANCANGAN DAN REALISAS I}

\section{A. Perancangan Program Aplikasi}

Sistem yang dirancang adalah Sistem Pendukung Sistem Pendukung Keputusan ini memiliki beberapa menu diantaranya Menu Supplier, Menu Barang, Menu Penilaian Supplier, Menu Pemilihan supplier dan Menu Rekap Hasil Supplier. Menu Supplier berisikan data umum dari supplier seperti alamat dan telepon. Menu Barang berisikan data-data barang seperti jenis, merek barang, nama barang dan harga barang.

Menu Penilaian Supplier berisikan halaman untuk melakukan penilaian dari masing-masing supplier berdasarkan kriteria dan sub kriteria yang telah ditetapkan olah pemilik toko. Menu Pemilihan Supplier merupakan suatu halaman dimana saat pemilik toko akan melakukan restrok barang, lalu sistem akan menampilkan hasil perengkingan supplier. Menu Rekap Hasil Supplier berisikan rekap 
hasil dari pe milihan supplier dimana dapat dilaku kan filter berdasarkan tahun dan bulan.

\section{B. Realisasi Program Aplikasi}

1. Analisa Kebutuhan User

Wawancara dilakukan untuk mengetahui informasi yang berkaitan dengan perhitungan Metode Profile Matching. Setelah dilakukannya wawancara, terdapat beberapa kriteria dan sub kriteria yang digunakan untuk penilaian. Berikut merupakan hasil wawancara yang didapatkan:

- Kriteria Harga (Bobot 40\%)

\section{TAB EL 2 Kriteria Harga}

\begin{tabular}{lll}
\hline Nama sub kriteria & $\begin{array}{c}\text { Pengelombokan } \\
\text { faktor }\end{array}$ & $\begin{array}{c}\text { Nilai } \\
\text { target }\end{array}$ \\
\hline Harga barang & core factor & 4 \\
\hline $\begin{array}{l}\text { Perincian pencatatan } \\
\text { harga }\end{array}$ & secondary factor & 2 \\
\hline $\begin{array}{l}\text { Lama tatuh tempo } \\
\text { pembay aran }\end{array}$ & secondary factor & 3 \\
\hline
\end{tabular}

- $\quad$ Kriteria Kualitas (Bobot 30\%)

TABEL 3 Kriteria Kualitas

\begin{tabular}{|c|c|c|}
\hline Nama sub kriteria & $\begin{array}{c}\text { Pengelompokan } \\
\text { faktor }\end{array}$ & $\begin{array}{l}\text { Nila } \\
\text { targe }\end{array}$ \\
\hline $\begin{array}{l}\text { Tingkat kecacatan } \\
\text { barang }\end{array}$ & core factor & \\
\hline Ketahanan produk & secondary factor & \\
\hline \\
\hline Nama sub kriteria & Pengelompol & Nilai \\
\hline & faktor & target \\
\hline $\begin{array}{l}\text { Kemudahan untuk } \\
\text { dihubungi }\end{array}$ & & \\
\hline $\begin{array}{l}\text { Kemudahan dalar } \\
\text { pengembalian bar }\end{array}$ & core factor & \\
\hline $\begin{array}{l}\text { Ketepatan dalam } \\
\text { pengiriman }\end{array}$ & core factor & 4 \\
\hline $\begin{array}{l}\text { Ketepatan jumlah dan } \\
\text { jenis barang yang } \\
\text { dikirim }\end{array}$ & core factor & 4 \\
\hline $\begin{array}{l}\text { Proses pelay anan } \\
\text { garansi }\end{array}$ & secondary factor & 3 \\
\hline $\begin{array}{l}\text { Riway at ketersediaan } \\
\text { barang }\end{array}$ & secondary factor & 3 \\
\hline Sikap & secondary factor & 2 \\
\hline $\begin{array}{l}\text { Kecepatan pengiriman } \\
\text { barang }\end{array}$ & seondary factor & 3 \\
\hline Tarif pengiriman & secondary factor & 3 \\
\hline
\end{tabular}

\section{Usecase Diagram}

Pada Gambar 1 usecase diagram, terdapatnya dua aktor yang terlibat pada sistem yaitu admin dan pemilik toko. Kedua aktor tersebut melakukan login sebelum mengakses sistem. Admin dan pemilik toko mengelo la data supplier dan data barang, terdapatnya proses create, update, delete, search dan view data supplier dan data barang. Pemilik toko melakukan penilaian pada masing-masing supplier dan dapat melihat data supplier yang belum dilakukan penilaian.

Saat pemilik toko melakukan proses restok barang, pemilik toko memilih barang lalu sistem menampilkan rekomendasi supplier, dimana dapat dijadikan sebagai bahan pertimbangan pemilihan. Pemilik toko juga dapat memasukan notes atau keterangan pemilihan. Pemilik toko dan ad min dapat melihat rekap data supplier yang telah dipilih serta dapat melakukan cetak data supplier. User dapat mengakses profil dimana user dapat melihat data profil, mengubah profil dan mengubah password.

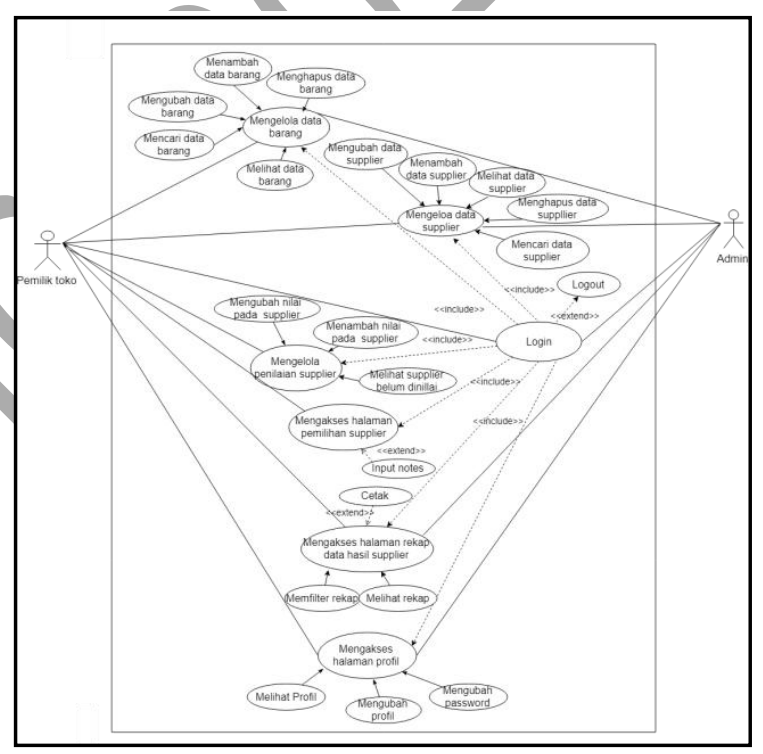

Gambar 1 Usecase Diagram

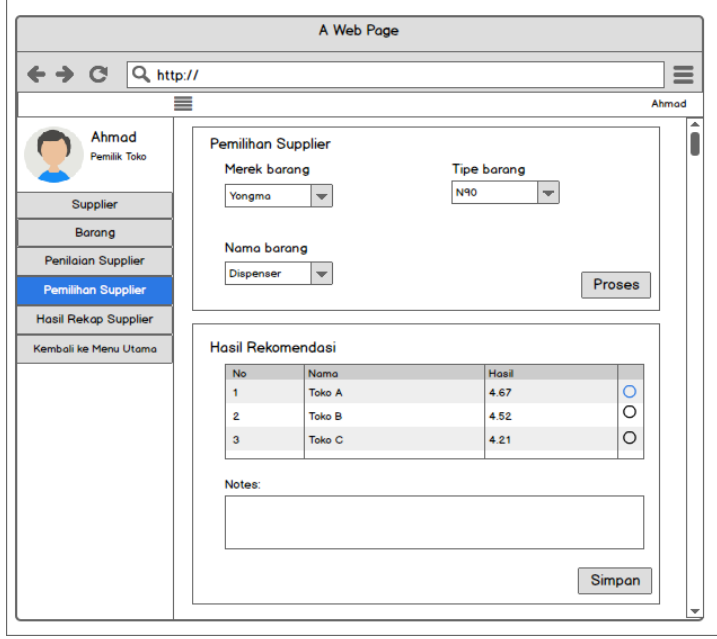

Gambar 2 Mockup Halaman Pemilihan Supplier

3. Imple mentasi Sistem 
User memilih merek barang, nama barang dan tipe barang lalu memilih to mbol proses setelah itu sistem menampilkan hasil rekomendasi supplier. User memilih salah satu hasil supplier setelah itu user juga dapat memasukkan notes atau keterangan pemilihan setelah itu memilih tombol simpan. Gambar 3 merupakan implementasi halaman user melakukan pemilihan supplier.

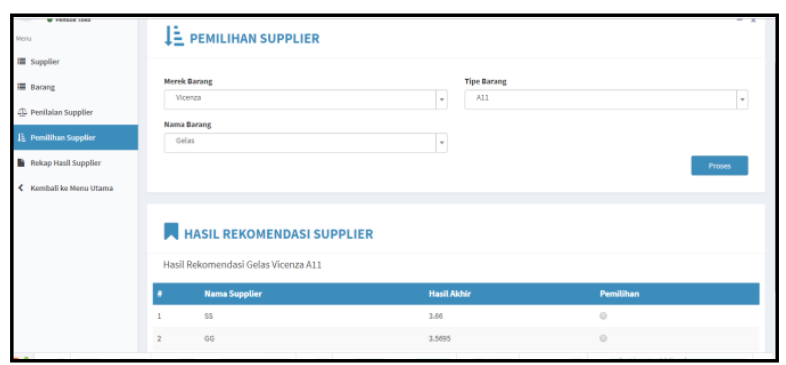

Gambar 3 Implementasi Halaman Pemilihan Supplier

4. Implementasi Metode Profile Matching

Contoh kasus yang digunakan yaitu melakukan pemilihan supplier saat akan melakukan restok barang dengan nama setrika, merek barang philips dan dengan tipe hd1172. Terdapatnya tiga supplier yang menjadi alternatif pemilihan. Berikut adalah langkah-langkah yang digunakan yaitu sebagai berikut:

1. Menentukan Kriteria

Dalam pemilihan supplier kriteria telah ditetapkan oleh pemilik toko dimana dilihat pada TABEL 1 s.d. TABEL 3.

\section{Melakukan Pemetaan GAP}

Untuk mendapatkan nilai gap dilakukan operasi pengurangan dari masing-masing nilai atribut dengan nilai target. Sedangkan untuk mendapatkan nilai bobot maka dilakukan pemetaan nilai gap terhadap nilai bobot dan dapat dilihat pada tabel

\section{- Kriteria Harga}

\section{TAB EL 5 Pemetaan Kriteria Harga}

\begin{tabular}{|c|c|c|c|c|}
\hline Alternat if & $\mathrm{A}$ & $\bar{B}$ & $\bar{C}$ & Ket \\
\hline Supplier 1 & 5 & 1 & 3 & \multirow{3}{*}{ Nilai Atribut } \\
\hline Supplier 2 & 4 & 1 & 4 & \\
\hline Supplier 3 & 2 & 5 & 3 & \\
\hline $\begin{array}{l}\text { Nilai } \\
\text { Target }\end{array}$ & 4 & 2 & 3 & \\
\hline Supplier 1 & 1 & -1 & 0 & \multirow{3}{*}{ Gap } \\
\hline Supplier 2 & 0 & -1 & -1 & \\
\hline Supplier 3 & -2 & 3 & 0 & \\
\hline \multicolumn{5}{|c|}{ Pemetaan Bobot } \\
\hline Supplier 1 & 1 & -1 & 0 & \multirow{3}{*}{ Bobot } \\
\hline Supplier 2 & 0 & -1 & -1 & \\
\hline Supplier 3 & -2 & 3 & 0 & \\
\hline
\end{tabular}

Keterangan:
A : harga barang, B :perincian pencatatan harga,

$\mathrm{C}$ :lama jatuh tempo pembayaran

- $\quad$ Kriteria Kualitas

TABEL 6 Pemetaan Kriteria Harga

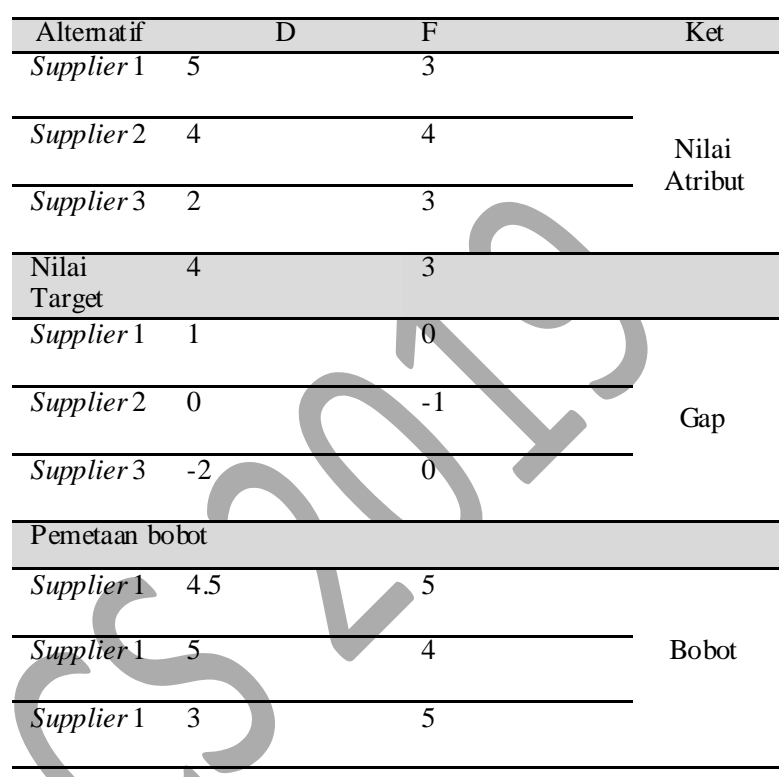

Keterangan:

D : tingkat kecacatan barang, E :ketahanan produk

Kriteria Pelayanan

TABEL 7 Pemetaan Kriteria Pelayanan

\begin{tabular}{|c|c|c|c|c|c|c|c|c|c|c|}
\hline $\begin{array}{l}\text { Altern } \\
\text { atif }\end{array}$ & $\bar{F}$ & $\bar{G}$ & $\overline{\mathrm{H}}$ & $\begin{array}{l}I \\
\end{array}$ & $\mathrm{~J}$ & $\bar{K}$ & L & $\bar{M}$ & $\bar{N}$ & \\
\hline $\begin{array}{l}\text { Suppli } \\
\text { er } 1\end{array}$ & 1 & 4 & 3 & 1 & 5 & 3 & 1 & 4 & 4 & \\
\hline $\begin{array}{l}\text { Suppli } \\
\text { er } 2\end{array}$ & 1 & 1 & 4 & 3 & 3 & 3 & 4 & 5 & 4 & \\
\hline $\begin{array}{l}\text { Suppli } \\
\text { er } 3\end{array}$ & 4 & 3 & 4 & 3 & 4 & 3 & 3 & 5 & 3 & \\
\hline $\begin{array}{l}\text { Nilai } \\
\text { Target }\end{array}$ & 4 & 4 & 4 & 4 & 3 & 3 & 2 & 3 & 3 & \\
\hline $\begin{array}{l}\text { Suppli } \\
\text { er } 1\end{array}$ & $\overline{-3}$ & 0 & -1 & -3 & 2 & 0 & -1 & 1 & 1 & $\mathrm{Cl}$ \\
\hline $\begin{array}{l}\text { Suppli } \\
\text { er } 2\end{array}$ & -3 & -3 & 0 & -1 & 0 & 0 & 2 & 2 & 1 & $\mathrm{a}$ \\
\hline $\begin{array}{l}\text { Suppli } \\
\text { er } 3\end{array}$ & 0 & -1 & 0 & -1 & 1 & 0 & 2 & 2 & 0 & $\mathrm{p}$ \\
\hline \multicolumn{11}{|c|}{ Pemetaan bobot } \\
\hline $\begin{array}{l}\text { Suppli } \\
\text { er } 1\end{array}$ & 2 & 5 & 4 & 2 & $\begin{array}{l}3 . \\
5\end{array}$ & 5 & 4 & $\begin{array}{l}4 . \\
5\end{array}$ & $\begin{array}{l}4 . \\
5\end{array}$ & $\begin{array}{l}\mathrm{B} \\
\mathrm{o}\end{array}$ \\
\hline $\begin{array}{l}\text { Suppli } \\
\text { er } 2\end{array}$ & 2 & 2 & 5 & 4 & 5 & 5 & 5 & $\begin{array}{l}3 . \\
5\end{array}$ & $\begin{array}{l}4 . \\
5\end{array}$ & $\begin{array}{l}\mathrm{b} \\
\mathrm{o}\end{array}$ \\
\hline
\end{tabular}




\begin{tabular}{|l|l|l|l|l|l|l|l|l|l|l|}
\hline $\begin{array}{l}\text { Suppli } \\
\text { er } 3\end{array}$ & 5 & 4 & 5 & 4 & 4. & 5 & 5 & 3. & 5 & $\mathrm{t}$ \\
\hline
\end{tabular}

Keterangan:

$\mathrm{F}$ :kemudahan untuk dihubungi, $\mathrm{G}$ :kemudahan dalam pengembalian barang, $\mathrm{H}$ :ketepatan dalam pengiriman, I :ketepatan jumlah dan jenis barang yang dikirim, $\mathrm{J}$ :proses pelayanan garansi, $\mathrm{K}$ :riwayat ketersediaan barang, L sikap, $\mathrm{M}$ :kecepatan pengiriman barang

$\mathrm{N}$ :tarif pengiriman

3. Pengelompokan Core Factor dan Secondary Factor

Mencari nilai rata-rata untuk core factor dan secondary factor pada masing-maisng kriteria.

- Kriteria Harga

TAB EL 8 Pengelompokan Faktor pada Kriteria

\begin{tabular}{lll}
\multicolumn{3}{c}{ Harga } \\
\hline \multicolumn{1}{c}{ Alternat if } & Nilai CF & Nilai SF \\
\hline Supplier 1 & $4.5 / 1=4.5$ & $(4+5) / 2=4.5$ \\
\hline Supplier 2 & $5 / 1=5$ & $(4+4) / 2=4$ \\
\hline Supplier 3 & $3 / 1=3$ & $(2.5+5) / 2=3.8$ \\
\hline
\end{tabular}

- Kriteria Kualitas

TAB EL 9 Pengelompokan Faktor pada Kriteria Kualitas

\begin{tabular}{lll}
\hline Alternat if & Nilai CF & Nilai SF \\
\hline Supplier 1 & $4 / 1=4$ & $4.5 / 1=4.5$ \\
\hline Supplier 2 & $2 / 1=2$ & $3 / 1=3$ \\
\hline Supplier 3 & $4.5 / 1=4.5$ & $3.5 / 1=3.5$
\end{tabular}

- Kriteria Pelayanan

TAB EL 10 Pengelompokan Faktor pada Kriteria

\begin{tabular}{lll} 
& \multicolumn{2}{c}{ Pelayanan } \\
\hline Alternatif & Nilai CF & Nilai SF \\
\hline Supplier 1 & $(2+5+4+2) / 4$ & $(3.5+5+4+4.5+4.5) / 5$ \\
& $=3.25$ & $=4.3$ \\
\hline Supplier 2 & $(2+2+5+4) / 4$ & $(5+5+3.5+3.5+4.5) / 5$ \\
& $=3.25$ & $=4.3$ \\
\hline Supplier 3 & $(5+4+5+4) / 4$ & $(4.5+5+3.5+3.5+5) / 5$ \\
& $=4.5$ & $=4.3$ \\
\hline
\end{tabular}

4. Perhitungan Nilai Total Tiap Kriteria

Pehitungan nilai total dilakukan pada masingmasing krietria. Untuk perhitungan nilai total nilai core factor memiliki persantase $60 \%$ dan untuk secondary factor Memiliki persentase sebesar $40 \%$.

- $\quad$ Kriteria Harga

TABEL 11 Nilai Total pada Kriteria Harga

\begin{tabular}{lc}
\hline Alternatif & Nilai Total \\
\hline Supplier 1 & $((60 / 100) * 4.5)+((40 / 100) * 4.5)=4.5$ \\
\hline Supplier 2 & $((60 / 100) * 5)+((40 / 100) * 4)=4.6$ \\
\hline Supplier3 & $((60 / 100) * 3)+((40 / 100) * 3.8)=3.3$ \\
\hline
\end{tabular}

- Kriteria Kualitas

TAB EL 12 Nilai Total pada Kriteria Kualitas

\begin{tabular}{lc}
\hline Alternatif & Nilai Total \\
\hline Supplier 1 & $((60 / 100) * 4)+((40 / 100) * 4.5)=4.2$ \\
\hline Supplier 2 & $((60 / 100) * 2)+((40 / 100) * 3)=2.4$ \\
\hline Supplier 3 & $((60 / 100) * 4.5)+((40 / 100) * 3.5)=4.1$
\end{tabular}

- Kriteria Pelayanan

TABEL 13 Nilai Total pada Kriteria Pelayanan

\begin{tabular}{lc}
\hline Alternatif & Nilai Total \\
\hline Supplier 1 & $((60 / 100) * 3.25)+((40 / 100) * 4.3)=4$ \\
\hline Supplier 2 & $((60 / 100) * 3.25)+((40 / 100) * 4.3)=4$ \\
\hline Supplier 3 & $((60 / 100) * 4.5)+((40 / 100) * 4.3)=4$
\end{tabular}

5. Perhitungan Penentuan Ranking

TABEL 14 Hasil Perengkingan

\begin{tabular}{|c|c|c|c|}
\hline Alternat if & Hasil R & nking & \\
\hline & $((40 / 100) * 4.5)$ & $((30 / 100) * 4.2)$ & + \\
\hline & $((30 / 100) * 4)=4.161$ & & \\
\hline Supplier 2 & $((40 / 100) * 4.6)$ & $((30 / 100) * 2.4)$ & + \\
\hline & $((30 / 100) * 4)=3.661$ & & \\
\hline Supplier 3 & $((40 / 100) * 3.3)$ & $\left((30 / 100)^{*} 4.1\right)$ & + \\
\hline & $((30 / 100) * 4)=3.876$ & & \\
\hline
\end{tabular}

Berdasarkan TABEL 14 terlihat bahwa supplier 1 lebih unggu dibanding supplier lainnya dengan nilai akhir 4.161. Jadi Berdasarkan perhitunggan menggunakan Metode Profile Matching yang terpilih yaitu supplier 1 .

\section{ANALIS IS DAN PEMB AHASAN}

A. Pengujian Hasil Metode Profile Matching

Selain dilakukannya pengujian dari sisi fungsionalitas sistem, dilakukanya pengujian akurasi. Pengujian dilakukan dengan membandingkan hasil perhitungan secara manual yaitu dengan menggunakan Microsoft Excel dan dengan menggunakan Metode Profile Matching. Hasil yang diperoleh dapat dilihat pada TABEL 15:

TAB EL 15 Perbandingan Hasil Perh itungan Metode Profile Matching

\begin{tabular}{lcc}
\hline $\begin{array}{c}\text { Nama } \\
\text { Supplier }\end{array}$ & $\begin{array}{c}\text { Perhit ungan } \\
\text { Manual }\end{array}$ & $\begin{array}{c}\text { Perhitungan Profile } \\
\text { Matching }\end{array}$ \\
\hline SM & 4.161 & 4.161 \\
\hline CPP & 4.0925 & 4.0925
\end{tabular}




\begin{tabular}{lll}
\hline SS & 3.876 & 3.9 \\
\hline K & 3.661 & 3.661 \\
\hline GG & 3.5695 & 3.5695 \\
\hline
\end{tabular}

\section{B. Analisis Pengujian Perbandingan Hasil}

Pe milihan Supplier Data Real dan Metode Profile Matching

Total item uji yaitu sebanyak 10 data. Dari 10 data tersebut terdapatnya 2 data yang tidak sesuai dan 8 data yang sesuai dengan pencatatan hasil supplier sebelumnya. Persentase keberhasilan dari pengujian ini yaitu $80 \%$. Terdapatnya data yang tidak sesuai sebesar $20 \%$, dimana terdapatnya hasil pemilihan data tidak sesuai dengan hasil yang didapat dengan menggunakan sistem. Dalam perhitungan profile matching apabila supplier berada di posisi bawah/tidak terpilih disebabkan karena memiliki gap yang besar dan bobot yang kecil. Berdasarkan pengujian yang dilakukan, analisis yang didapatkan yaitu supplier harus mendapatkan nilai yang tinggi untuk kriteria yang memiliki persentase terbesar.

Selain itu harus mendapatkan nilai gap yang kecil sehingga bobot yang didapatkan bernilai besar dan kemungkinan mendapatkan posisi yang teratas semakin besar pula. Nilai gap di dapatkan dari operasi pengurangan antara penilaian pada masingmasing sub kriteria dengan nilai target, dimana nilai target telah di tetapkan oleh decision maker. Berdasarkan pengujian yang dilakukan didapatkan bahwa bobot mempengaruhi proses perhitungan. Pada sisi lainnya, terdapatnya data yang tidak sesuai juga dipengaruhi oleh ketersediaan barang saat akan memilih supplier. Sistem ini hanya sebagai bahan pertimbangan dan alat bantu dalam pengambilan keputusan. Sistem ini hanya menjadi alat bantu bagi pengambil keputusan, dimana pada kasus ini yaitu pemilik toko, keputusan akhir tetap berada ditangan pengambil keputusan.

\section{KESIMPULAN}

Perancangan dan pembangunan Sistem Pendukung Keputusan pemilihan supplier dengan Metode Profile Matching pada Toko Maju Jaya telah berhasil dilakukan. Sistem ini dapat memberikan rekomendasi atau bahan pertimbangan pemilihan supplier oleh pemilik toko saat akan melakukan restok barang serta dapat menghilangan unsur subjektifitas pemilihan. Sistem ini juga dapat membantu admin dalam mengetahui supplier yang telah dipilih oleh pemilik toko. Pada pengujian perbandingan data real dan dengan menggunakan Metode Profile Matching memperoleh persentase keberhasilan sebes ar $80 \%$.

\section{REFERENS I}

[1] Hasdi, R. F., P. Sudarmaningtyas, \& A. Supriyanto. 2014. "Rancang Bangun Sistem Pendukung Keputusan Pemilihan Supplier pada Derry Auto Service dengan Metode AHP". Jurnal Sistem Informasi, 3(2), 90-96.

[2] Rais, M. D. 2016. "Sistem Pendukung Keputusan Untuk Pemilihan Lokasi Perumahan Menggunakan Analytical Hierarchy Process (AHP)". Riau Joumal Of Computer Science, 2(2), 59-72.

[3] Nofriansyah, D., \& S. Defit. 2017.Multi Criteria Decision Making (MCDM) pada Sistem Pendukung Keputusan. Yogyakarta: Deepublish.

[4] Nugroho, R. P.A, \& Purwanto. 2015. "Rancangan Sistem pendukung Keputusan Penerimaan Pegawai Menggunakan MetodeProfil Matching”. Explore Informatika, 5(1), 33-42.

[5] Mulyani, S. 2017. Metode Analisis dan Perancangan Sistem (Edisi 2). Bandung: Abdi Sistematika.

[6] Sopianti, L., \& Bachtiar, N. 2015. "Students Major Determination Decision Support Systems using Profile Matching Method with SMS Gateway Implement at ion. Jurnal Sains dan Matematika", 23(1),14-24.

[7] Yurindara.2017. Software Engineering. Yogyakarta:Deepublish.

[8] Mulyani, 2016.Sistem Informasi Manamjemen Rumah Sakit:Analisis dan Perancangan. Bandung:Abdi Sistematika.

[9] Ling, L. S. 2016. Mengenali Pemasok Merupakan Langkah Penting Dalam Mengubah Rantai Pasokan. https://www.smart-tbk.com/mengenali-pemasok-merupakanlangkah-penting-dalam-men gubah-rantai-pasokan/. 1 Maret $2018(22: 06)$

[10] Hikmat. 2016. Perbedaan antara Pemasok dan Distributor. http://kliksma.com/2016/08/perbedaan-antara-pemasok-dandistributor.html. 1 Maret 2018 (20:00).

[11] Pasaribu. 2017. "Penerapan Framework Yii Pada Pembangunan Sistem Ppdb Smp Bppi Baleendah Kabupaten Bandung". Jurnal Ilmiah Teknologi Informasi Terapan, $2407-3911$.

[12] Zakir. 2017. "Implementasi T eknologi Framework Yii pada Aplikasi Berbasis Web". Jumal Nasional Informatika dan Teknologi Jaringan, 2540-7600. 